\title{
RISK MANAGEMENT IN PREVENTING MEDICATION ERRORS IN A COMMUNITY PHARMACY
}

\author{
ANA-MARIA OLTEAN, OFELIA CRIŞAN * \\ Department of Pharmaceutical Legislation and Management, Faculty of Pharmacy, "Iuliu Haţieganu" University of Medicine \\ and Pharmacy Cluj-Napoca, 12 Ion Creangă Street, Cluj-Napoca, Romania
}

*corresponding author: ofelia.crisan@umfcluj.ro

Manuscript received: March 2017

\begin{abstract}
The aim of this paper was to create a model for a risk management plan for preventing the medication errors in a community pharmacy. Our objectives were to present useful tools for the community pharmacists to manage such errors and a practical example of identifying risk minimisation strategies. Following the brainstorming method, the most important medication errors were identified. Using the affinity diagram, they were grouped into prescribing, dispensing and administration errors. Within the prioritization matrix, these errors were classified using as criteria: patient safety, relevance for pharmacists, human resources needed and the cost of implementing a risk minimisation strategy. The medication errors were classified based on the final score and risk management strategies were proposed for each of them. The risk management plan is essential in preventing medication errors and can be an important part in the policy of quality assurance in a community pharmacy activity.
\end{abstract}

\section{Rezumat}

Scopul lucrării a fost elaborarea unui model de plan de management al riscului pentru prevenirea erorilor de medicaţie în farmacia comunitară. Obiectivele lucrării includ prezentarea unor instrumente utile în gestionarea erorilor şi identificarea unor strategii de reducere a riscului de apariţie a acestora. Prin metoda brainstormingului, s-au identificat categoriile de erori de medicaţie ce apar în practică. Utilizând diagrama afinităţilor, ele s-au grupat în erori de prescriere, de eliberare şi de administrare. Folosind o matrice de prioritizare, erorile s-au clasificat după următoarele criterii: siguranţa pacientului, relevanța pentru farmacistul din farmacie, resursele umane necesare şi costul implementării strategiei de management al riscului. Erorile au fost ordonate în ordinea descrescătoare a scorului obţinut şi s-au propus strategii de minimizare a riscurilor. Planul de management al riscului este esenţial în prevenirea erorilor de medicaţie, fiind un element important în politica de asigurare a calităţii în activitatea farmaciei.

Keywords: risk management, medication errors, community pharmacy, patient safety, human resources

\section{Introduction}

Currently, systems of quality assurance in the pharmaceutical field, based on the rules of good practice (manufacturing, distribution, pharmacovigilance) include, necessarily, the risk management activities. This is the case for manufacturers, wholesale distributors and authorities in the field of medicine, when dealing with pharmacovigilance activities [1114]. It's not the same for pharmacies because there are no harmonized rules of good pharmacy practice, formalizing the concept of risk management. However, both nationally and internationally, guidelines on good pharmacy practice recommend to establish quality standards that would limit or minimize the risks of error in the pharmacy's activities [20, 27]. In addition to commercial risks, pharmacists in community pharmacies deal with professional risk, including medication errors, of many types and categories; the occurrence of these errors is related to several factors, such as the presentation of the medicinal product $[1-3,8,29]$, the way a prescription is written
[1-3, 25, 29], staff training, work environment, including organizational culture [34, 36, 39], the absence of risk management strategies or their inefficiency in implementing [1-3, 8, 9, 36]. The risks of adverse events caused by medication errors are important $[2,4$, $8,10,29]$, therefore guidelines on good practice were developed, including at European level, for registration, coding, reporting and evaluation of medication errors or risk minimization and prevention of these $[15,16$, $19,37]$. At the national level, in some countries the competent authorities have adopted official documents and strategies for reducing medication errors. Recent research in this area, whether it refers to the activity of the hospital or that of the community pharmacy, demonstrates the need for a better understanding of the incidence and nature of these errors [3-5, 22, 24], to develop efficient risk management strategies [10, $25,30]$, especially to prevent or minimize them to maximize patient safety [32-34, 39]. In Romania, although the concern for quality assurance in the community pharmacy has increased in recent years $[6,7,17,35]$, there are still no official steps to 
implement risk management strategies at this level. The purpose of this paper was to develop an example of a risk management plan for the most important medication errors encountered in a community pharmacy. The work objectives included presenting useful tools in the management of these errors by pharmacists and a practical example of identifying strategies to minimize the risk of medication errors.

\section{Materials and Methods}

To identify medication errors that may occur in a community pharmacy, the brainstorming method was used, as a useful creative method for the quality management [18]. The method was applied together with health professionals, pharmacists with experience in different fields (pharmaceutical industry, community pharmacy, hospital pharmacy) and a specialised physician. Because the brainstorming does not always provide the most objective assessment of the identified problems, we used this method combined with other tools, which are designed to classify the items identified [18]. To group medication errors identified, based on their relationships, the affinity diagram was used [21, 38]. Because of the large number of possible errors (identified) and limited resources that a pharmacy can have at a time, it may be necessary to prioritize resources allocation. In this respect, we exemplified the use of a prioritization matrix. In creating a prioritization matrix, an important aspect is setting the criteria to be considered for prioritization and that are important to everyone involved, respectively the establishing of the rating scale. Each rating is a numerical value that indicates the extent to which that criterion is important in setting priorities, including in relation to other criteria, i.e. its share in the overall evaluation. For each criterion, a specific score is calculated using both its rating and the importance or the weight of that specific criterion for each evaluated medication error [23, 28, 31]. Given our intention to develop a risk management plan, we have established four criteria that we consider in the process of prioritizing medication errors. These criteria are: patient safety; relevance to the community pharmacist, which refers to the ability/right of the pharmacist to make a change at the time of dispensing the medication; human resources required for risk mitigation; the cost of implementing a risk management strategy.
The score assigned to each medication errors for each criterion was between 1 and 5, as follows: "Patient safety" criterion: 1 is assigned to medication errors which do not endanger the safety of the patient, and 5 is assigned to medication errors that jeopardize patient safety; "Relevance to the community pharmacist" criterion: 1 is assigned to medication errors for which the community pharmacist cannot implement a strategy of risk management, and 5 is assigned to medication errors for which the pharmacist can play an important role in establishing risk management strategies; "Human resources required for risk mitigation" criterion: 1 is assigned to medication errors which management requires additional human resources and 5 is assigned to medication errors that can be managed without additional human resources; "The cost of implementing a risk management strategy" criterion: 1 is assigned to medication errors for which implementing a risk management strategy involves additional financial resources, and 5 is assigned to medication errors for which implementing a risk management strategy does not imply additional financial resources.

Considering that this plan is meant for implementing effective risk management strategies in a community pharmacy, we decided to assign to the "relevance to the community pharmacist" criterion a weight of 3 and to the "human resources required for risk mitigation" criterion a weight of 2 . For the other two criteria, we have decided to assign a weight of 1 .

After establishing the criteria, rating scale and weight, the prioritization matrix was created. In a square matrix, the first column lists all errors identified, by category, and the first row lists the prioritization criteria established. The next step in completing the matrix was to assign to each error, for each criterion, a score from 1 to 5 , then to multiply each of those scores with the weight established for each criterion, followed by summing up these partial scores to obtain a total score per error. Thus, the applied prioritization matrix regarding medication errors are depicted in Table I.

Based on the scores obtained, medication errors were ordered from high to low. After that, risk minimization strategies were set out for each error. Depending on available resources, these strategies were implemented based on the order established in the prioritization matrix. This paper suggests examples of strategies to prevent medication errors in a community pharmacy.

Table I

A model for the prioritization matrix

\begin{tabular}{|l|c|c|c|c|c|}
\hline & $\begin{array}{c}\text { Patient safety } \\
\text { (A x 1) }\end{array}$ & $\begin{array}{c}\text { Relevance for } \\
\text { the community } \\
\text { pharmacist } \\
\text { (B x 3) }\end{array}$ & $\begin{array}{c}\text { Human resources } \\
\text { required for risk } \\
\text { mitigation } \\
(\mathbf{C} \times \mathbf{2})\end{array}$ & $\begin{array}{c}\text { The cost of } \\
\text { implementing a risk } \\
\text { management strategy } \\
\text { (D x 1) }\end{array}$ & Final score \\
\hline Medication error 1 & $\mathrm{A} 1 \times 1$ & $\mathrm{~B} 1 \times 3$ & $\mathrm{C} 1 \times 2$ & $\mathrm{D} 1 \times 1$ & $\mathrm{~A} 1+3 \mathrm{~B} 1+2 \mathrm{C} 1+\mathrm{D} 1$ \\
\hline Medication error 2 & $\mathrm{A} 2 \times 1$ & $\mathrm{~B} 2 \times 3$ & $\mathrm{C} 2 \times 2$ & $\mathrm{D} 2 \times 1$ & $\mathrm{~A} 2+3 \mathrm{~B} 2+2 \mathrm{C} 2+\mathrm{D} 2$ \\
\hline Medication error 3 & $\mathrm{A} 3 \times 1$ & $\mathrm{~B} 3 \times 3$ & $\mathrm{C} 3 \times 2$ & $\mathrm{D} 3 \times 1$ & $\mathrm{~A} 3+3 \mathrm{~B} 3+2 \mathrm{C} 3+\mathrm{D} 3$ \\
\hline
\end{tabular}




\section{Results and Discussion}

After applying the brainstorming method, 35 categories of medication errors have been initially identified, as following: wrong prescribing of medicinal product considering the indications; wrong prescribing of medicinal product considering the contraindications; wrong prescribing of medicinal product considering the patient's known allergies; prescribing a wrong dose of medicinal product; dispensing a wrong pharmaceutical form; prescribing a wrong amount of medicinal product; dispensing a wrong amount of medicinal product; wrong choice of administration route; dispensing a wrong concentration of medicinal product; wrong frequency in administering the medicinal product; wrong dosage regimen; illegible writing; prescribing a too high dose of a medicinal product; prescribing a too low dose of a medicinal product; wrong formulation; improper storage of a medicinal product; wrong technique of administration; dispensing an expired medicinal product; dispensing a medicinal product with damaged packaging; failure to monitor an important parameter; administering a wrong concentration of medicinal product to a child or new-born; wrong information about the patient in the medical record or prescription; administering a wrong dose of medicinal product; omission of medicinal products from a senior citizen medication; wrong counselling; dispensing a wrong medicinal product with resembling outer packaging; dispensing a wrong medicinal product with resembling commercial name; prescribing a medicinal product from a wrong therapeutic class; administering a wrong dose of medicinal product to a child or new-born, based on a miscalculation related to the weight in $\mathrm{kg}$; wrong dilution when preparing a solution; prescribing a dose $/ \mathrm{kg}$ body weight to a child, but omitting the final dose calculation/administration; wrong dispensing/administering due to misinterpretation of milligrams (mg) as micrograms (mcg); not changing the dose when changing the administration route; wrong splitting of a medicinal product; wrong replacement of a medicinal product.

"Illegible writing" was considered a medication error category, because it is possible that the pharmacist may not correctly understand the prescribing physician handwriting and accidentally release another drug with a resembling name. "Wrong formulation" was considered an error category that may occur in the preparation of medicinal products in pharmacy. "Prescribing the wrong dose of medicinal product" error category may include cases more specific, such as "Prescribing a too high dose" and "Prescribing a too low dose", for which just one category was kept i.e. "Prescribing the wrong dose of medicinal product".

\begin{tabular}{|c|c|c|}
\hline Prescribing errors & Dispensing errors & Administering errors \\
\hline $\begin{array}{l}\text { Wrong prescribing of medicinal product } \\
\text { considering the indications }\end{array}$ & $\begin{array}{c}\text { Dispensing a wrong pharmaceutical } \\
\text { form }\end{array}$ & $\begin{array}{c}\text { Administering a wrong dose of medicinal } \\
\text { product }\end{array}$ \\
\hline $\begin{array}{l}\text { Wrong prescribing of medicinal product } \\
\text { considering the contraindications }\end{array}$ & $\begin{array}{l}\text { Dispensing a wrong amount of } \\
\text { medicinal product }\end{array}$ & Wrong choice of administration route \\
\hline $\begin{array}{l}\text { Wrong prescribing of medicinal product } \\
\text { considering the patient's known allergies }\end{array}$ & $\begin{array}{l}\text { Dispensing a wrong concentration of } \\
\text { medicinal product }\end{array}$ & $\begin{array}{l}\text { Wrong frequency in administering the } \\
\text { medicinal product }\end{array}$ \\
\hline $\begin{array}{l}\text { Prescribing a wrong dose of medicinal } \\
\text { product }\end{array}$ & Wrong dosage regimen & Wrong technique of administration \\
\hline $\begin{array}{c}\text { Prescribing a wrong amount of medicinal } \\
\text { product }\end{array}$ & $\begin{array}{l}\text { Dispensing an expired medicinal } \\
\text { product }\end{array}$ & $\begin{array}{l}\text { Administering a wrong dose of medicinal } \\
\text { product to a child or new-born, based on a } \\
\text { miscalculation related to the weight in } \mathrm{kg}\end{array}$ \\
\hline Illegible writing & $\begin{array}{c}\text { Dispensing a medicinal product with } \\
\text { damaged packaging }\end{array}$ & $\begin{array}{l}\text { Administering a wrong concentration of } \\
\text { medicinal product to a child or new-born }\end{array}$ \\
\hline Failure to monitor an important parameter & Wrong counselling & \\
\hline $\begin{array}{l}\text { Wrong information about the patient in } \\
\text { the medical record or prescription }\end{array}$ & $\begin{array}{l}\text { Dispensing a wrong medicinal product } \\
\text { with resembling outer packaging }\end{array}$ & \\
\hline $\begin{array}{l}\text { Omission of medicinal products from a } \\
\text { senior citizen medication }\end{array}$ & $\begin{array}{l}\text { Dispensing a wrong medicinal product } \\
\text { with resembling commercial name }\end{array}$ & \\
\hline $\begin{array}{l}\text { Prescribing a medicinal product from a } \\
\text { wrong therapeutic class }\end{array}$ & $\begin{array}{l}\text { Wrong dispensing/administering due } \\
\text { to misinterpretation of mg as mcg }\end{array}$ & \\
\hline $\begin{array}{c}\text { Prescribing a dose/kg bw to a child, but } \\
\text { omitting the final dose calculation/ } \\
\text { administration }\end{array}$ & $\begin{array}{l}\text { Wrong information about the patient } \\
\text { in the medical record or prescription }\end{array}$ & \\
\hline $\begin{array}{l}\text { Wrong dispensing/administering due to } \\
\text { misinterpretation of mg as mcg }\end{array}$ & $\begin{array}{c}\text { Wrong splitting of a medicinal } \\
\text { product }\end{array}$ & \\
\hline \multicolumn{3}{|l|}{$\begin{array}{l}\text { Not changing the dose when changing the } \\
\text { administration route }\end{array}$} \\
\hline Wrong replacement of a medicinal product & & \\
\hline
\end{tabular}


FARMACIA, 2018, Vol. 66, 4

Thus, the categories of errors to be included in the affinity diagram were only 33 . Based on their relationships, the identified medication errors were grouped into three categories: prescribing errors, dispensing errors and administering errors (Table II). Of the 33 medication errors identified, three errors could not be classified in any of the categories, namely: "Wrong formulation", "Improper storage of a medicinal product" and "Wrong dilution when preparing a solution". These were not included in the

prioritization matrix. One can observe that, overall, from the most encountered errors, 14 are prescribing errors, 12 dispensing errors and just 6 are administration errors. Also, two errors were classified into two categories, namely "Wrong dispensing/administering due to misinterpretation of $\mathrm{mg}$ as mcg" and "Wrong information about the patient in the medical record or prescription", which were classified both as prescribing errors, and dispensing errors. Further on, the prioritization matrix was drafted (Tables III - V).

Table III

Prioritization matrix for the identified prescribing errors

\begin{tabular}{|c|c|c|c|c|c|}
\hline & $\begin{array}{c}\text { Patient } \\
\text { safety }\end{array}$ & \begin{tabular}{|c|} 
Relevance to \\
the community \\
pharmacist \\
\end{tabular} & \begin{tabular}{|c|}
$\begin{array}{c}\text { Human resources } \\
\text { required for risk } \\
\text { mitigation }\end{array}$ \\
\end{tabular} & \begin{tabular}{|c|} 
The cost of implementing \\
a risk management \\
strategy
\end{tabular} & \begin{tabular}{|l|} 
Total \\
score
\end{tabular} \\
\hline $\begin{array}{l}\text { Wrong prescribing of medicinal product } \\
\text { considering the indications }\end{array}$ & $5 \times 1$ & $1 \times 3$ & $5 \times 2$ & $4 \times 1$ & 22 \\
\hline $\begin{array}{l}\text { Wrong prescribing of medicinal product } \\
\text { considering the contraindications }\end{array}$ & $5 \times 1$ & $1 \times 3$ & $5 \times 2$ & $4 \times 1$ & 22 \\
\hline $\begin{array}{l}\text { Wrong prescribing of medicinal product } \\
\text { considering the patient's known allergies }\end{array}$ & $5 \times 1$ & $1 \times 3$ & $5 \times 2$ & $4 \times 1$ & 22 \\
\hline $\begin{array}{l}\text { Prescribing a wrong dose of medicinal } \\
\text { product }\end{array}$ & $5 \times 1$ & $5 \times 3$ & $5 \times 2$ & $5 \times 1$ & 35 \\
\hline $\begin{array}{c}\text { Prescribing a wrong amount of medicinal } \\
\text { product }\end{array}$ & $5 \times 1$ & $5 \times 3$ & $5 \times 2$ & $5 \times 1$ & 35 \\
\hline Illegible writing & $5 \times 1$ & $5 \times 3$ & $5 \times 2$ & $5 \times 1$ & 35 \\
\hline Failure to monitor an important parameter & $5 \times 1$ & $1 \times 3$ & $5 \times 2$ & $5 \times 1$ & 23 \\
\hline $\begin{array}{l}\text { Wrong information about the patient in the } \\
\text { medical record or prescription }\end{array}$ & $5 \times 1$ & $4 \times 3$ & $5 \times 2$ & $5 \times 1$ & 32 \\
\hline $\begin{array}{l}\text { Omission of medicinal products from a } \\
\text { senior citizen medication }\end{array}$ & $5 \times 1$ & $1 \times 3$ & $5 \times 2$ & $5 \times 1$ & 23 \\
\hline $\begin{array}{l}\text { Prescribing a medicinal product from a } \\
\text { wrong therapeutic class }\end{array}$ & $5 \times 1$ & $1 \times 3$ & $5 \times 2$ & $5 \times 1$ & 23 \\
\hline $\begin{array}{l}\text { Prescribing a dose } / \mathrm{kg} \text { bw to a child, but } \\
\text { omitting the final dose calculation/administration }\end{array}$ & $5 \times 1$ & $5 \times 3$ & $5 \times 2$ & $5 \times 1$ & 35 \\
\hline $\begin{array}{l}\text { Wrong dispensing/administering due to } \\
\text { misinterpretation of mg as mcg }\end{array}$ & $5 \times 1$ & $5 \times 3$ & $5 \times 2$ & $5 \times 1$ & 35 \\
\hline $\begin{array}{l}\text { Not changing the dose when changing the } \\
\text { administration route }\end{array}$ & $5 \times 1$ & $3 \times 3$ & $5 \times 2$ & $5 \times 1$ & 29 \\
\hline
\end{tabular}

Table IV

Prioritization matrix for the identified dispensing errors

\begin{tabular}{|c|c|c|c|c|c|}
\hline & $\begin{array}{c}\text { Patient } \\
\text { safety }\end{array}$ & $\begin{array}{c}\text { Relevance to the } \\
\text { community } \\
\text { pharmacist }\end{array}$ & $\begin{array}{c}\text { Human resources } \\
\text { required for risk } \\
\text { mitigation }\end{array}$ & $\begin{array}{c}\text { The cost of } \\
\text { implementing a risk } \\
\text { management strategy }\end{array}$ & $\begin{array}{c}\text { Total } \\
\text { score }\end{array}$ \\
\hline Wrong replacement of a medicinal product & $5 \times 1$ & $5 \times 3$ & $5 \times 2$ & $5 \times 1$ & 35 \\
\hline Dispensing a wrong pharmaceutical form & $5 \times 1$ & $5 \times 3$ & $5 \times 2$ & $4 \times 1$ & 34 \\
\hline $\begin{array}{c}\text { Dispensing a wrong amount of medicinal } \\
\text { product }\end{array}$ & $5 \times 1$ & $5 \times 3$ & $5 \times 2$ & $5 \times 1$ & 35 \\
\hline $\begin{array}{c}\text { Dispensing a wrong concentration of } \\
\text { medicinal product }\end{array}$ & $5 \times 1$ & $5 \times 3$ & $5 \times 2$ & $4 \times 1$ & 34 \\
\hline $\begin{array}{c}\text { Wrong dosage regimen } \\
\text { Dispensing an expired medicinal product }\end{array}$ & $5 \times 1$ & $5 \times 3$ & $5 \times 2$ & $3 \times 1$ & 33 \\
\hline $\begin{array}{c}\text { Dispensing a medicinal product with } \\
\text { damaged packaging }\end{array}$ & $2 \times 1$ & $5 \times 3$ & $5 \times 2$ & $5 \times 1$ & 35 \\
\hline Wrong counselling & $3 \times 1$ & $5 \times 3$ & $5 \times 2$ & 38 \\
\hline $\begin{array}{c}\text { Dispensing a wrong medicinal product with } \\
\text { resembling outer packaging }\end{array}$ & $5 \times 1$ & $5 \times 3$ & $5 \times 2$ & $5 \times 1$ & 31 \\
\hline $\begin{array}{c}\text { Dispensing a wrong medicinal product with } \\
\text { resembling commercial name }\end{array}$ & $5 \times 1$ & $5 \times 3$ & $5 \times 2$ & $5 \times 1$ & 35 \\
\hline
\end{tabular}


FARMACIA, 2018, Vol. 66, 4

\begin{tabular}{|c|c|c|c|c|c|}
\hline \hline & $\begin{array}{c}\text { Patient } \\
\text { safety }\end{array}$ & $\begin{array}{c}\text { Relevance to the } \\
\text { community } \\
\text { pharmacist }\end{array}$ & $\begin{array}{c}\text { Human resources } \\
\text { required for risk } \\
\text { mitigation }\end{array}$ & $\begin{array}{c}\text { The cost of } \\
\text { implementing a risk } \\
\text { management strategy }\end{array}$ & $\begin{array}{c}\text { Total } \\
\text { score }\end{array}$ \\
\hline $\begin{array}{c}\text { Wrong dispensing/administering due to } \\
\text { misinterpretation of mg as mcg }\end{array}$ & $5 \times 1$ & $5 \times 3$ & $5 \times 2$ & $5 \times 1$ & 35 \\
\hline $\begin{array}{c}\text { Wrong information about the patient in the } \\
\text { medical record or prescription }\end{array}$ & $4 \times 1$ & $5 \times 3$ & $5 \times 2$ & $5 \times 1$ & 34 \\
\hline Wrong splitting of a medicinal product & $4 \times 1$ & $3 \times 3$ & $5 \times 2$ & $5 \times 1$ & 28 \\
\hline
\end{tabular}

Table V

Prioritization matrix for the identified administering errors

\begin{tabular}{|c|c|c|c|c|c|}
\hline & $\begin{array}{l}\text { Patient } \\
\text { safety }\end{array}$ & $\begin{array}{l}\text { Relevance to the } \\
\text { community } \\
\text { pharmacist }\end{array}$ & \begin{tabular}{|c|}
$\begin{array}{c}\text { Human resources } \\
\text { required for risk } \\
\text { mitigation }\end{array}$ \\
\end{tabular} & $\begin{array}{c}\text { The cost of } \\
\text { implementing a risk } \\
\text { management strategy }\end{array}$ & $\begin{array}{l}\text { Total } \\
\text { score }\end{array}$ \\
\hline $\begin{array}{l}\text { Administering a wrong dose of medicinal } \\
\text { product }\end{array}$ & $5 \times 1$ & $5 \times 3$ & $5 \times 2$ & $5 \times 1$ & 35 \\
\hline Wrong choice of administration route & $5 \times 1$ & $3 \times 3$ & $5 \times 2$ & $5 \times 1$ & 29 \\
\hline $\begin{array}{l}\text { Wrong frequency in administering the } \\
\text { medicinal product }\end{array}$ & $5 \times 1$ & $5 \times 3$ & $5 \times 2$ & $5 \times 1$ & 35 \\
\hline Wrong technique of administration & $5 \times 1$ & $5 \times 3$ & $5 \times 2$ & $5 \times 1$ & 35 \\
\hline $\begin{array}{l}\text { Administering a wrong dose of medicinal } \\
\text { product to a child or new-born, based on a } \\
\text { miscalculation related to the weight in } \mathrm{kg}\end{array}$ & $5 \times 1$ & $3 \times 3$ & $5 \times 2$ & $5 \times 1$ & 29 \\
\hline $\begin{array}{l}\text { Administering a wrong concentration of } \\
\text { medicinal product to a child or new-born }\end{array}$ & $5 \times 1$ & $5 \times 3$ & $5 \times 2$ & $5 \times 1$ & 35 \\
\hline
\end{tabular}

Based on the final score obtained after developing the matrix, errors were ranked in the order of their addressing priority. A total of 14 errors obtained the maximum score of 35 points: prescribing a wrong dose of medicinal product; prescribing a wrong amount of medicinal product; illegible writing; prescribing a dose $/ \mathrm{kg}$ bw to a child, but omitting the final dose calculation/administration; wrong dispensing/ administering due to misinterpretation of $\mathrm{mg}$ as $\mathrm{mcg}$; dispensing a wrong amount of medicinal product; wrong replacement of a medicinal product; dispensing an expired medicinal product; dispensing a wrong medicinal product with resembling outer packaging; dispensing a wrong medicinal product with resembling commercial name; wrong frequency in administering the medicinal product; wrong technique of administration; administering a wrong dose of medicinal product; administering a wrong concentration of medicinal product to a child or new-born.

The reason for this result was that those errors can affect patient safety, errors that the community pharmacist can avoid relatively easily by implementing measures to minimize the risk without additional costs or human resources.

Several errors obtained a score between 28 and 34 points: dispensing a wrong pharmaceutical form; dispensing a wrong concentration of medicinal product; wrong information about the patient in the medical record or prescription; wrong dosage regimen; wrong counselling; administering a wrong dose of medicinal product to a child or new-born, based on a miscalculation related to the weight in $\mathrm{kg}$; wrong choice of administration route; not changing the dose when changing the administration route; wrong splitting of a medicinal product; dispensing a medicinal product with damaged packaging.

Those scores, close to the top, show that it is necessary to implement risk management measures, but not very expensive, as it will be seen below.

The minimum score of 22 points, or very close to the minimum, of 23 points, was obtained through 6 medication errors: omission of medicinal products from a senior citizen medication; prescribing a medicinal product from a wrong therapeutic class; failure to monitor an important parameter; wrong prescribing of medicinal product considering the indications; wrong prescribing of medicinal product considering the contraindications; wrong prescribing of medicinal product considering the patient's known allergies.

This is the case for prescribing errors committed by the physician but identified by the pharmacist. The easiest way to correct these errors would be the refusal of dispensing the treatment, but with negative consequences for the patients' rights. A better communication between the prescriber and the pharmacist, including advice about the appropriate medication, would be the best strategy. But, in Romania, there is no such a consistent collaborative relationship between the physician and the pharmacist. Therefore, these cases have been regarded as difficult to manage by pharmacists.

The purpose of applying these methods was to identify, analyse and classify, considering the priorities and risks to patient safety, medication errors that may occur in a community pharmacy, to include them in a risk 
FARMACIA, 2018, Vol. 66, 4

management plan. This plan will include strategies to prevent or to minimize the risk of errors, to be implemented in the pharmacy. Examples of such strategies are set forth below.

Participating to specific continuing education, including, if appropriate, joint programmes with physicians and/ or patients, is a risk minimization strategy identified as needed in order to avoid many medication errors, such as: prescribing a wrong dose of medicinal product or a wrong amount of medicinal product, wrong dispensing/administering due to misinterpretation of mg as mcg, wrong replacement of a medicinal product, wrong frequency in administering the medicinal product, administering a wrong concentration or dose of medicinal product to a child or new-born, dispensing a wrong pharmaceutical form or a wrong concentration of medicinal product, wrong information about the patient in the medical record or prescription, wrong dosage regimen, wrong counselling, wrong choice of administration route, not changing the dose when changing the administration route, omission of medicinal products from a senior patient medication, prescribing a medicinal product from a wrong therapeutic class, failure to monitor an important parameter, wrong prescribing of medicinal product considering the indications, contraindications and patient's known allergies.

For prescribing a wrong dose of medicinal product or a wrong amount of medicinal product, a strategy like establishing protocols containing the recommended doses is needed. For illegible writing, the best strategy is to implement an electronic prescribing system and/ or printed medical letters/prescriptions. For prescribing a dose $/ \mathrm{kg}$ bw to a child, but omitting the final dose calculation/administration, a solution can be to introduce, in the pharmacy management software, a list of the most common dosages, doses $/ \mathrm{kg}$, total dose/ administration, and to set an alarm leading to opening a window showing the appropriate dose, for verification before dispensing a medicinal product.

Implementing a standard operating procedure for dispensing medicinal products is one of the best risk minimization strategy for several dispensing medication errors, such as: wrong replacement of a medicinal product, dispensing an expired medicinal product, dispensing a wrong medicinal product with resembling outer packaging, dispensing a wrong medicinal product with resembling commercial name, dispensing a wrong amount of medicinal product, dispensing a wrong pharmaceutical form or a wrong concentration of medicinal product, wrong dosage regimen, wrong counselling, wrong choice of administration route, wrong splitting of a medicinal product, dispensing a medicinal product with damaged packaging (a standard operating procedure is needed also for the reception of medicinal products, including a quality check of medicinal products received, in order to establish if the cause of damaged packaging is one that falls under the responsibility of the manufacturer/wholesale distributor/transporter).

Wrong replacement of a medicinal product, dispensing a wrong medicinal product with resembling commercial name and dispensing a wrong pharmaceutical form or a wrong concentration of medicinal product can also be avoided by using a pharmaceutical management software that enables a decrease in stocks by scanning the barcode, compared with the scanned or existing prescription in an electronic system.

For dispensing an expired medicinal product, other strategies can be useful: implementing in the pharmacy management software the function of providing a report concerning medicinal products that are approaching expiry date, installing visual or audible alarms which alert the pharmacist when there are expired medicinal products in stock, or implementing a standard operating procedure to regularly check the expiry dates. For dispensing a wrong medicinal product with resembling outer packaging or commercial name, complementary strategies can be used: identifying such products, implementing a storage system which prevents confusion of such medicinal products, implementing a colour/form code applied by all pharmacists, making possible to differentiate products with resembling outer packaging, or setting visual or audible alarms in the pharmacy management software which alert the pharmacist when issuing a wrong product. The last one can be also applied in order to avoid dispensing a wrong pharmaceutical form or a wrong concentration of medicinal product.

Wrong frequency in administering the medicinal product can be prevented by making a schedule for the patient, specifying the times at which the medicinal product should be administered, and by implementing a mobile app that will remind the patient, either by texting or by another visual/audible alarm, the time of administration. The administration of the medicinal product and the technique of administration can be improved by making schemes/drawings easy to understand and remember by patients and by applying stickers in pharmacies with specific images for different routes of administration.

Administering the right concentration/dose of medicinal product to a child or new-born can be managed by establishing standard protocols for the most common situations, followed by implementing in the pharmacy management software a list of the most common dosages, doses $/ \mathrm{kg}$, total dose $/$ administration, and setting an alarm leading to opening a window showing the appropriate dose, for verification before dispensing a medicinal product.

Wrong information about the patient in the medical record or prescription, omission of medicinal products from a senior citizen medication, prescribing a medicinal product from a wrong therapeutic class, failure to monitor an important parameter, wrong 
FARMACIA, 2018, Vol. 66, 4

prescribing of medicinal product considering the indications, contraindications and patient's known allergies are medication errors that can be better managed by establishing a standard protocol for referrals to physicians or agreement of cooperation between physicians and pharmacists, based on a concurred format adopted by their professional associations.

As can be seen, measures have been proposed relating both to the pharmacist training and tools that can be made available to the pharmacist, as additional means of control. Participating to specific continuing education, improving communication with the patient and the physician, may significantly contribute to reducing errors made by the community pharmacist.

Additionally, the use of standard operating procedures and protocols designed and implemented according to the particularities of the pharmacy, is necessary. Materials provided by software companies, manufacturers or even developed by community pharmacists, can be used in everyday work, resulting in decreasing the number of errors. Avoiding medication errors is possible, as indicated by other authors [2, 5, 10, 17], but needs reporting and implementation of coherent strategies in practice [25, 32-36, 39], including measures such those proposed in this paper.

Even if these measures can be implemented in a community pharmacy, under the form of a specific risk management plan, their effectiveness needs to be evaluated and, if necessary, these measures can be adjusted or replaced with more suitable ones, depending on the context, developments or resources of each pharmacy.

\section{Conclusions}

Quality assurance in a community pharmacy should involve risk management activities designed to prevent medication errors or reduce the number and impact on the health and safety of patients. To this end, in the absence of formal approaches or initiatives in this respect, community pharmacies from Romania can use methods that can be applied or adapted adequately to meet the needs of pharmacists in the management of medication errors. The brainstorming method can be used to easily identify the most common medication errors that pharmacies face, whereas the affinity diagram and prioritization matrix can be useful in classification and prioritization.

Identifying and implementing strategies to minimize the risk of medication errors is then up to the community pharmacist and pharmacy staff, depending on the importance and seriousness of the risk and the resources available within the pharmacy. The most important strategies for minimizing the risks of medication errors refer to specific continuing education, the need to use modern technologies for the management of medicines and specific tools of communication in the relationship with the patient and with the physician. Creating a risk management plan, with preventive and corrective actions, is an essential step in addressing medication errors and their consequences on patients.

\section{References}

1. Aronson JK, Medication errors: definitions and classification. Brit J Clinical Pharmacology, 2009; 67(6): 599-604.

2. Aronson JK, Medication errors: what they are, how they happen and how to avoid them. QJM, 2009; 102(8): 513-521.

3. Ashcroft DM, Quinlan P, Blenkinsopp A, Prospective study of the incidence, nature and causes of dispensing errors community pharmacies. Pharmacoepidemiology and Drug Safety, 2005; 14(5): 327-332.

4. Bohand X, Simon L, Perrier E, Mullot H, Lefeuvre L, Plotton C, Frequency, types, and potential clinical significance of medication-dispensing errors. Clinics, 2009; 64(1): 11-16.

5. Boyle TA, Mahaffey T, MacKinnon NJ, Deal H, Hallstrom LK, Morgan H, Determinants of medication incident reporting, recovery, and learning in community pharmacies: A conceptual model. Research in Social and Administrative Pharmacy, 2011; 7(1): 93-107.

6. College of Pharmacists of Romania, Decision no. 1/ 2011 approving procedures for evaluating the respect of good pharmacy practice. Off J of Romania, Part I, no. 170/2011, amended, (available in Romanian).

7. College of Pharmacists of Romania, Iacob S (coordinator), Legislation and templates of procedures for implementing the good pharmacy practice. 2011, www.colegfarmbv.ro, (available in Romanian).

8. Cohen MR, Medication Errors, $2^{\text {nd }}$ Ed.. Washington DC: Am. Pharmacists Assoc., 2007, www.pharmacylibrary.com.

9. De Silva T, Essential management skills for pharmacy and business managers., CRC Press, Taylor\&Francis Group, Boca Raton, London, New York, 2013, 57-74.

10. Glavin RJ, Drug errors: consequences, mechanisms, and avoidance. Br J Anaesthesia, 2010; 105(1): 76-82.

11. European Commission, Guidelines of 5 November 2013 on Good Distribution Practice of medicinal products for human use. Official Journal of the European Union, C343/23.11.2013.

12. European Commission, Public Health, Eudralex Volume 4 Good manufacturing practice (GMP) Guidelines, www.ec.europa.eu.

13. European Medicines Agency, ICH Guideline Q9 on quality risk management. 2015, www.ema.europa.eu.

14. European Medicines Agency, Guideline on good pharmacovigilance practices (GVP), Modul V - Risk management systems (Rev1). 2014, www.ema.europa.eu.

15. European Medicines Agency, Good practice guide on recording, coding, reporting and assessment of medication errors. 2015, www.ema.europa.eu.

16. European Medicines Agency, Good practice guide on risk minimisation and prevention of medication errors. 2015, www.ema.europa.eu.

17. Iancu M, Bucşa C, Fărcaş A, Leucuţa D, Dincu A, Mogoşan C, Dumitraşcu DL, Bojiţă M, Patient's counselling and management of adverse drug 
reactions and drug interactions in the community pharmacy. Farmacia, 2015; 63(1): 80-85.

18. Ilieş L, Management of total quality. Ed. Dacia, Cluj-Napoca, 2003, 299-301, (available in Romanian).

19. Institute of Medicine of the National Academies. Fact Sheet: What You Can Do to Avoid Medication Errors, 2006, www.nationalacademies.org.

20. International Pharmaceutical Federation, World Health Organization, Joint FIP/WHO Guidelines on Good Pharmacy Practice: Standards for Quality of Pharmacy Services. WHO Technical Report Series, No. 961, 2011, Annex 8: 310-323.

21. Ioniţă I, Management of quality for technical and economic systems. www.biblioteca-digitala.ase.ro, (available in Romanian).

22. Koczorowska-Cerbin M, Waszyk-Nowaczyk M, Odor K, Michalak M, Piotrowska S, Matschay A, Simon M, Majchrzycki M, Pharmaceutical care as a chance of improving health care in areas with an average level of urbanization. Farmacia, 2017; 65(1): 159-166.

23. Latino RJ, Patient Safety. The PROACT ${ }^{\mathbb{B}}$ root cause analysis approach. Taylor\&Francis Group, 2009; 31-39.

24. Madden ME, Ball PA, The decision-making processes of pharmacists in inland Australia - a pilot study. Rural and Remote Health, 2011; 11(2): 1-13.

25. Mahoney CD, Berard-Collins CM, Coleman R, Amaral JF, Cotter CM, Effects of an integrated clinical information system on medication safety in a multi-hospital setting. American Journal of HealthSystem Pharmacy, 2007; 64(18): 1969-1977.

26. McDowell SE, Ferner HS, Ferner RE, The pathophysiology of medication errors: how and where they arise. Br J Clinic Pharmacology, 2009; 67(6): 605-613.

27. Ministry of Health, Order no. $75 / 2010$ approving Rules for good pharmacy practice. Off J of Romania, Part I, no. 91/2010, (available in Romanian).

28. Minnesota Department of Health, MDH QI Toolbax, Prioritization Matrix. 2014, www.health.state.mn.us.
29. O'Donnell J, Randy Vogenberg F, Legal risk management opportunities, pharmacy practice, and P\&T committees, Part 1: Deconstructing dispensing errors. Pharmacy and Therapeutics, 2014; 39(8): 559-579.

30. O'Donnell J, Randy Vogenberg F, Legal risk management opportunities, pharmacy practice, and P\&T committees, Part 2: Risk management recommendations. Pharmacy and Therapeutics, 2014; 39(9): 624-626.

31. Office of Quality Improvement, University of WisconsinMadison, Project Prioritization. A structured approach to working on what matters most. 2012, www.oqi.wisc.edu.

32. Pereira Guerreiro M, Martins AP, Cantrill JA, Preventable drug-related morbidity in community pharmacy: commentary on the implications for practice and policy of a novel intervention. Int J Clinic Pharm., 2012; 34(5): 682-685.

33. Pereira Guerreiro M, Martins AP, Cantrill JA, Preventable drug-related morbidity in community pharmacy: development and pilotiong of a complex intervention. Int J Clinic Pharm., 2012; 34(5): 699-709.

34. Sanghera IS, Franklin BD, Dhillon S, The attitudes and beliefs of healthcare professionals on the causes and reporting of medication errors in a UK Intensive care unit. Anaesthesia, 2007; 62(1): 53-61.

35. Tăerel AE, Soroceanu V, Rais C, Stancu E, Study of quality standards application in Bucharest community pharmacies. Farmacia, 2014; 62(6): 1082-1088.

36. Tong B, Ho C, Risk Management in Community Pharmacy. ISMP Canada Safety Bulletin, Pharmacy Connection, 2013; 33-37, www.ismp-canada.org.

37. US Food and Drug Administration, Medication Errors Related to Drugs, www.fda.gov.

38. US Navy Pacific Fleet's Handbook for Basic Process Improvement (BPI), www.au.af.mil.

39. Waeschle RM, Bauer M, Schmidt CE, Errors in medicine. Causes, impact and improvement measures to improve patient safety. Der Anaesthesist, 2015; 64(9): 689-704. 